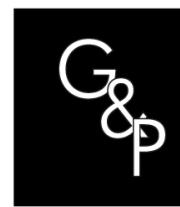

Thematic

Section

Digital

Transformation,

Intelligent

Manufacturing

and Supply

Chain

Management 4.0

\title{
An enterprise model on Sensing, Smart, and Sustainable ( $\left.\mathbf{S}^{\wedge} \mathbf{3}\right)$ enterprises
}

\author{
Um modelo de empresas sobre empresas Sensing, Smart e \\ Sustainable $\left(S^{\wedge} 3\right)$
}

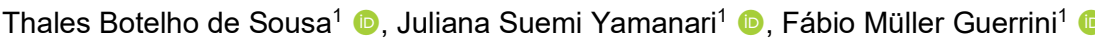 \\ ${ }^{1}$ Universidade de São Paulo - USP, Escola de Engenharia de São Carlos - EESC, Departamento de Engenharia \\ de Produção, Programa de Pós-graduação em Engenharia de Produção, São Carlos, SP, Brasil. E-mail: \\ thales.botelho@ifsp.edu.br; jusuemi@hotmail.com; guerrini@sc.usp.br
}

How to cite: Sousa, T. B., Yamanari, J. S., \& Guerrini, F. M. (2020). An enterprise model on Sensing Smart, and Sustainable $\left(\mathrm{S}^{\wedge} 3\right)$ enterprises. Gestão \& Produção, 27(3), e5624.

https://doi.org/10.1590/0104-530X5624-20

\begin{abstract}
Organizations are being highly pressured to increase their competitiveness in order to deal with dynamic and turbulent markets. The development of an intelligent manufacturing system has been identified as an effective way to increase the competitiveness of enterprises. Traditional companies need models, skills, processes, and technologies to face the challenges imposed by today's highly competitive markets, which require constant innovation. Sensing, Smart, and Sustainable $\left(S^{\wedge} 3\right)$ Enterprises play an important role in the digitization of strategies, decisions, and operations. They become efficient in facing the challenges intrinsic to the digital economy and intelligent manufacturing by applying the concepts of detection and monitoring, intelligence, and sustainability. The extant literature indicates the need for the development of methods and enterprise models that portray the reality of $S^{\wedge} 3$ Enterprises. This paper presents an enterprise model to facilitate the formalization of $S^{\wedge} 3$ Enterprises and help understand the dynamics of their operations. Applying the For Enterprise Modeling (4EM) method, this proposed enterprise model documents the goals, business rules, processes, and concepts of $S^{\wedge} 3$ Enterprises. The contribution of this paper is the identification of guiding principles that allow companies interested in applying the $S^{\wedge} 3$ concepts to have a basic reference mapped through perspectives of different knowledge domains.
\end{abstract}

Keywords: Sensing Enterprise; Smart Enterprise; Sustainable Enterprise; Enterprise modeling; Intelligent manufacturing.

Resumo: As organizações estão sendo altamente pressionadas para aumentar sua competitividade para lidar com os mercados dinâmicos e turbulentos, e o desenvolvimento de um sistema de manufatura inteligente foi identificado como uma forma eficaz de aumentar a competitividade das empresas. Portanto, as empresas tradicionais necessitam de modelos, habilidades, processos e tecnologias para enfrentar os desafios impostos pelos atuais mercados altamente competitivos, o que exige inovação constante. Ao aplicarem os conceitos de detecção e monitoramento, inteligência e sustentabilidade, Empresas Sensing, Smart e Sustainable ( $\mathrm{S}^{\wedge} 3$ ) desempenham um papel importante na digitalização de estratégias, decisões e operações e tornam-se eficientes para enfrentar os desafios intrínsecos à economia digital e à manufatura inteligente. A literatura existente indica a necessidade do desenvolvimento de métodos e

Received Jun. 30, 2019 - Accepted Oct. 24, 2019

Financial support: This study was financed in part by the Coordenação de Aperfeiçoamento de Pessoal de Nível Superior - Brasil (CAPES) - Finance Code 001.

This is an Open Access article distributed under the terms of the Creative Commons Attribution License, which permits unrestricted use, distribution, and reproduction in any medium, provided the original work is properly cited. 
modelos de empresas que retratem a realidade das Empresas $\mathrm{S}^{\wedge} 3$. Este artigo tem como objetivo desenvolver um modelo de empresas para facilitar a formalização de Empresas $S^{\wedge} 3$ e compreender a dinâmica de suas operações. Aplicando o método For Enterprise Modeling (4EM), este modelo de empresas proposto documenta os objetivos, regras de negócio, processos e conceitos das Empresas $S^{\wedge} 3$. A contribuição deste artigo é a identificação de princípios norteadores que permitam que as empresas interessadas em aplicar os conceitos $S^{\wedge} 3$ tenham uma referência básica mapeada por meio de perspectivas de diferentes domínios do conhecimento.

Palavras-chave: Empresa Sensing; Empresa Smart; Empresa Sustainable; Modelagem de empresas; Manufatura inteligente.

\section{Introduction}

The scenario of intense competition among companies and the constant need for new technologies have increased flexibility of organizational structures, constantly compelling organizations to improve performance regarding their productive and managerial processes. We can see a direct relationship between competitiveness and innovation in products and processes, with emphasis on the development of new methodologies and structures to improve products, manufacturing processes, and productive structures constantly (OCDE, 2005; Schumpeter, 2008).

The evolution of Information and Communication Technology (ICT) has forced organizations to adopt new business models in order to enter and/or remain in highly competitive markets characterized by rapid and intense changes. Intelligent manufacturing implies a cloud manufacturing system comprised of men and machines, and designed to perform intelligent activities within the company (Liu et al., 2017; Zhong et al., 2016). This changes the management of the different enterprise units, the company as a whole, and the entire supply chain (Jia et al., 2016). Weichhart et al. (2016) introduced the concept of Sensing, Smart, and Sustainable $\left(S^{\wedge} 3\right)$ Enterprises, presenting the challenges and current developments of enterprise systems in the digital era. The $S^{\wedge} 3$ Reference Model is one of the industrial approaches for intelligent manufacturing, among others such as Industries 4.0, Made in China 2025, Industrial Internet, Internet +, and Advanced Manufacturing.

According to Seiger et al. (2015), intelligent manufacturing environments require appropriate modeling. Many languages, however, lack the structure, expressiveness, and flexibility necessary to represent their environment. For Pádua et al. (2004), enterprise modeling facilitates understanding of the enterprise environment. Mertins \& Jochem (2005) consider it a technique to represent and understand the structure and behavior of organizations, and a tool to analyze business processes. Techniques based on enterprise modeling provide the knowledge required to carry out process improvement, interoperability, integration, coordination, and decision-making within companies (De La Fuente et al., 2010).

Weichhart et al. (2016) also stated that $S^{\wedge} 3$ Enterprises need to face the challenges of the digital age but require proper formalization by means of models, methodologies, processes, tools, and appropriate technologies (Mauricio-Moreno et al., 2015). Enterprise modeling is fundamental to understand the connection among companies, the dynamics, strengths, and weaknesses (Braha et al., 2011). Further research is essential, applying emerging concepts such as those employed by $S^{\wedge} 3$ Enterprises to better understand modeling, management, and control in modern manufacturing (Panetto et al., 2019). 
Although there are technologies supporting the development of $S^{\wedge} 3$ Enterprises, companies lack methodologies to guide them in all related activities. This paper seeks to model the main elements found in $S^{\wedge} 3$ Enterprises using the For Enterprise Modeling (4EM) method. The enterprise model presented is designed to stimulate the application of $S^{\wedge} 3$ concepts in collaborative networks, describing how activities are structured by the members of different companies.

This paper is structured as follows: Section 2 defines the theoretical background on the topic. Section 3 describes the methods used to search, organize, and analyze the literature, to structure the case study, and to select the best method for enterprise modeling. Section 4 outlines the guiding principles for modeling applied in this study. Section 5 presents the overall enterprise model developed. Section 6 discusses the results and the contributions of each of the individual models developed. Finally, the last section outlines the conclusions of this work, pointing out its practical and scientific contributions, our critical positioning, the main limitations of this paper, and gaps to be explored in future researches.

\section{Theoretical background}

Enterprises must become sensing, smart, and sustainable $\left(S^{\wedge} 3\right)$ to face global challenges related to local, national, and global market dynamics (Miranda et al., 2019a). Modern enterprises must implement $S^{\wedge} 3$ concepts not only to manage their operations but also to develop their products, services, and manufacturing processes. The development of technologies based on these concepts will have a great positive impact in overall quality of life (Miranda et al., 2019b).

Efforts have been made to consolidate $S^{\wedge} 3$ Enterprises by integrating new technologies, and creating a generation of more efficient, agile, intelligent, and sustainable industrial systems. Camarinha-Matos et al. (2017) mapped the current needs of companies in which collaborative networks are essential to implement $\mathrm{S}^{\wedge} 3$ concepts. Marques et al. (2017) analyzed the barriers to industrial digitization and proposed several strategic, tactical, operational, and real-time approaches to assist in decision-making. Cortés et al. (2019) developed a representative model of a digital manufacturing plant based on the concepts of $S^{\wedge} 3$ Enterprises and the company's normal behavior for decision-making. The model contemplated all processes and their impact.

Panetto et al. (2019) pointed out some challenges facing the "factories of the future", such as the implementation of a highly customized supply network control, the creation of a resilient enterprise to cope with risks, the development of management support systems for decision-making, and the use of collaborative control. Palmer et al. (2017) developed a reference ontology to enable the interoperability of software tools involved in the global production of new Product-Services Systems (PSS). This had been suggested by Weichhart et al. (2016) as a challenge for $S^{\wedge} 3$ Enterprises.

The concept of sensing enterprise was created with the advent of augmented reality, representing an attempt to reconcile traditional internet-related organizations to the possibilities offered by the cyber world (Agostinho \& Jardim-Gonçalves, 2015). In this context, the sensing enterprise anticipates future decisions by capturing multidimensional information and creates an understanding of several scenarios by integrating decentralized intelligence, context awareness, dynamic configurability, and sensory technology during the decision-making process (Agostinho \& Jardim-Gonçalves, 2015; Vargas et al., 2016). A sensing enterprise also develops proactivity and dynamism for 
quick and efficient decision-making (Ferro-Beca et al., 2015; Zdravković et al., 2014), using sensors to detect events and measure changes in the environment (Miranda et al., 2019a).

Moisescu \& Sacala (2016) and Miranda et al. (2019a), following the same reasoning, explore Cyber-Physical Systems (CPS), which have as their main feature the sensing capability. It is activated by multiple network sensors and actuators (mechanical devices that apply force or produce motion) via Wireless Sensors Networks (WSN). These systems consist primarily of physical objects such as sensors, actuators, computing devices, and communication networks. In general, CPS collects a great amount of data from the physical environment through different types of sensors: cameras and sensors for humidity, infrared, air, and temperature, among others.

For Wright (2014), Mauricio-Moreno et al. (2015), and Almada-Lobo (2015), the use of sensor systems that monitor product behavior is what makes enterprises smart. Zhang et al. (2017) developed a framework for achieving continuous connectivity and real-time interoperability among manufacturing machines; it is the smart fabric of the future applying the CPS concept.

According to Filos (2006), the smart enterprise is a knowledge-driven and interconnected organization that quickly adapts to the changes and challenges of the competitive market. It is also flexible enough to create and explore knowledge in response to the opportunities of the digital age. Lee \& Chung (2016) noted that in these organizations all components are connected to each other through Wireless Sensor Networks (WSNs), Intelligent Operating Systems (IOSs), Internet of Things (loT), and Cyber-Physical Systems (CPSs). This minimizes energy consumption and the use of materials and maximizes environmental sustainability, health, safety, and economic competitiveness (Davis et al., 2012). CPSs combine embedded computers, networks, sensors, and actuators, all very important for smart organizations (Yue et al., 2015). Musa et al. (2014) propose these organizations can be coordinated as business-tobusiness, business-to-customer, and customer-to-customer interactions, and must manage their logistics infrastructure in terms of product availability and demand management. The productive units of smart enterprises employ dynamic and real-time collaboration towards the creation of value, the growth of the organization, and, ultimately, their survival (Busquets et al., 2009).

Veza et al. (2015) and Brodsky et al. (2017) agree that the key feature of smart enterprises is the production of highly customizable smart products. Products and services are integrated and high levels of collaboration are achieved through manufacturing networks. Trentesaux et al. (2016) argue that the smart dimension represents intelligent control of industrial products, processes, and systems. All future products and systems will be systematically connected.

The concept of sustainable enterprises is associated with the implementation of good manufacturing practices, reduction of manufacturing inputs, optimization of productive operations, and improvement of products. This minimizes the inherent environmental impacts that arise from product use and the end of its life cycle. Sustainable enterprises are aware of the challenges of global sustainable development and strive to minimize their ecological and social impacts, while maintaining good financial performance (Shrivastava \& Kennelly, 2013). Thus, in addition to environmental concerns, the sustainable enterprise must include social, economic, cultural, and ethical aspects (Chardine-Baumann \& Botta-Genoulaz, 2014; ChavarriaBarrientos et al., 2016; Peko et al., 2014). The economic performance of a company 
depends on the reliability of suppliers and consumers, the responsiveness of purchases, resources, and production, the flexibility of production and delivery, and the balance between finances and quality of products, services, and processes. Environmental performance depends on environmental certification, the use of resources (renewable energies, water reuse, recycling of products), the decrease of pollution and hazardous products, and the respect to natural environments (biodiversity, development of urban and rural areas). The social factor also encompasses cultural and ethical aspects. It is linked to working conditions, respect to human rights, social commitment (education, cultural and technological development, medical care), and corporate social responsibility in business practices. According to Zollo et al. (2013), the transition process to the sustainable enterprise model involves changes in the analysis of organizational peculiarities (business purpose and structure, shared values and beliefs) at the functional (specific processes and systems), and individual levels (value systems, beliefs, motivations, emotions, and psychological aspects).

Chavarria-Barrientos et al. (2018) stated that the $S^{\wedge} 3$ Enterprise must have nine active characteristics: context awareness, foresight, intelligence, collaboration, integration, adaptability/agility, economic sustainability, social responsiveness, and environmental sustainability. Table 1 presents a description of each characteristic.

Table 1. Description of the nine active characteristics of $S^{\wedge} 3$ Enterprises.

\begin{tabular}{|c|c|}
\hline Characteristic & Description \\
\hline Context awareness & $\begin{array}{l}\text { The ability to collect information about the enterprise. The information } \\
\text { can be internal (such as machine failures, product defects, cycle } \\
\text { times, machinery status) or external (downstream and upstream } \\
\text { capacity, demand fluctuations, costs). Sensors, WSNs, Radio } \\
\text { Frequency Identification (RFId), multi-sensors, and sensor fusion } \\
\text { support the process of collecting information. }\end{array}$ \\
\hline Foresight & $\begin{array}{l}\text { The ability to predict future changes, supported by CPSs, big data, } \\
\text { data mining, and machine learning. }\end{array}$ \\
\hline Intelligence & $\begin{array}{l}\text { The use of information or rules to make knowledge-based decisions. } \\
\text { This is done with the use of information models on products or } \\
\text { manufacturing, ontologies and artificial intelligence, intelligent control } \\
\text { systems and management systems [such as Supplier Relationship } \\
\text { Management (SRM), Customer Relationship Management (CRM), } \\
\text { Enterprise Resource Planning (ERP), and Manufacturing Execution } \\
\text { System (MES)]. }\end{array}$ \\
\hline Collaboration skills & $\begin{array}{l}\text { The enterprise's ability to conform to Collaborative Networked } \\
\text { Organizations (CNOs). ICTs, applications (such as wikis, blogs, e-mail, } \\
\text { social networks, chats, video-chat), and e-Services (such as e-Brokerage, } \\
\text { e-Marketing) support the collaboration among enterprises. }\end{array}$ \\
\hline Integration capability & $\begin{array}{l}\text { It can be structured at three levels: physical (interconnection of } \\
\text { devices and machines), application (integration of databases and } \\
\text { software), and business (coordination of management and control of } \\
\text { business processes). Integration is implemented through the use of } \\
\text { loT devices, device coordination systems [e.g. Supervisory Control } \\
\text { and Data Acquisition (SCADA), Programmable Logic Controllers } \\
\text { (PLCs)], management systems [e.g. ERP, MES, Product Data } \\
\text { Management (PDM)], enterprise modelling tools [e.g. ARIS, CIM } \\
\text { Tool, Bonapart], and enterprise operating systems. }\end{array}$ \\
\hline Adaptability/Agility & $\begin{array}{l}\text { The degree of flexibility in the kind of response obtained and in the } \\
\text { ease with which this response can be reconfigured as the } \\
\text { environment shifts again. This can be achieved using Computer } \\
\text { Numeric Control (CNC) machines, robotic arms, Automated Guided }\end{array}$ \\
\hline
\end{tabular}


Table 1. Continued...

\begin{tabular}{ll}
\hline \multicolumn{1}{c}{ Characteristic } & \multicolumn{1}{c}{ Description } \\
\hline & $\begin{array}{l}\text { Vehicle solutions (AGVs) and conveyors, Computer-Aided } \\
\text { Manufacturing (CAM) and Computer-Aided Process Planning } \\
\text { (CAPP) software, and Cyber-Physical Production Systems (CPPS). }\end{array}$ \\
\hline Economic sustainability & $\begin{array}{l}\text { The enterprise's ability to compete and generate profits. } \\
\text { Manufacturing strategies (lean manufacturing, mass production, } \\
\text { mass customization), business model patterns, accountability tools } \\
\text { (ERP, point of sales, Excel), and business intelligence are employed. }\end{array}$ \\
\hline Social responsiveness & $\begin{array}{l}\text { It is the ability to survive and meet the needs of society. It means } \\
\text { compliance with education programs, health insurance, employee } \\
\text { rights and related norms and standards. }\end{array}$ \\
\hline Environmental & $\begin{array}{l}\text { It involves the activities associated with three basics aspects: } \\
\text { products, process, and regulations, and can be developed by using } \\
\text { sustainability }\end{array}$ \\
$\begin{array}{l}\text { life-cycle assessment, additive manufacturing, product service } \\
\text { systems, and environmental standards such as ISO 14000. }\end{array}$ \\
\hline
\end{tabular}

\section{Methodology}

This study was developed through a comprehensive literature review, descriptive research, and enterprise modeling. It has a qualitative approach (providing greater proximity between the researchers and the problems studied) and presents both an exploratory (providing correlations among the objects of study to collaborate with future researches) and a descriptive characteristic (describing the characteristics of the object analyzed).

\subsection{Structuring of the descriptive research}

We initially carried out a bibliographic review of the theoretical foundations, principles, and concepts of an $S^{\wedge} 3$ Enterprise. We used the Scopus and Web of Science databases because of their great impact on the international academic community. The searches used the keywords "Enterprise Modeling", "Intelligent Manufacturing", "Sensing Enterprise* and Smart Enterprise*, and Sustainable Enterprise*".

After the bibliographic research, a descriptive research was carried out to obtain information that would enable the development and subsequent presentation of enterprise models related to $S^{\wedge} 3$ Enterprises. According to Cervo et al. (2007), descriptive research observes, records, analyzes, and correlates facts or phenomena without manipulating them. In descriptive research, the main techniques used to obtain information are questionnaires, interviews, and observations (Turrioni \& Mello, 2012).

We interviewed a specialist from a company currently implementing $S^{\wedge} 3$ concepts to model $\mathrm{S}^{\wedge} 3$ Enterprises. The professional interviewed was an employee of an optoelectronics technology company that produces medical, industrial, optical, aerospace, and defense components. In 2009, the company received the FINEP Innovation Award in the Medium Enterprise category. The professional has worked in import, export, purchasing, production planning and control, warehousing, receiving, and dispatching.

During the interview, we outlined the objectives of this paper. Later we submitted a version of the enterprise model presented in Section 5 to the professional interviewed so that it could be improved based on his experience and knowledge. 


\subsection{Selection of the enterprise modeling method}

Camarinha-Matos \& Afsarmanesh (2007) stated that modeling is fundamental for understanding, managing, simulating or predicting the network behavior in the context of a complex system as a collaborative network. Enterprise modeling is the most used technique for representing the knowledge of the company, with the support of models built to frame organization and performance (De La Fuente et al., 2010).

Pádua (2012) pointed out that enterprise modeling processes must bring answers to questions such as why, what, who, which, when, where, and how, using the various modeling techniques presented in the literature. Selecting the right technique is one of the essential stages in an enterprise-modeling project, and can substantially increase its success (Kassem et al., 2011). When choosing a modeling method, we should keep in mind who will read and use the models (Bertoni et al., 2009). It is important to compare the main methods used to perform the modeling process. Hence, Table 2 presents a classification of some of the main methods of enterprise modeling (Carvalho \& Guerrini, 2017; Daaboul et al., 2014; Guerrini \& Pellegrinotti, 2016; Lakhoua \& Rahmouni, 2011; Pádua et al., 2004).

Table 2. Classification of some of the main methods of enterprise modeling.

\begin{tabular}{cccccccc}
\hline Method & Objective & Decision & Activity & Data & Organization & Information & Process \\
\hline ARIS & - & - & $\mathrm{X}$ & $\mathrm{X}$ & $\mathrm{X}$ & $\mathrm{X}$ & $\mathrm{X}$ \\
\hline CIMOSA & $\mathrm{X}$ & - & $\mathrm{X}$ & $\mathrm{X}$ & $\mathrm{X}$ & $\mathrm{X}$ & $\mathrm{X}$ \\
\hline GERAM & $\mathrm{X}$ & $\mathrm{X}$ & - & $\mathrm{X}$ & - & $\mathrm{X}$ & - \\
\hline GRAI & - & $\mathrm{X}$ & $\mathrm{X}$ & - & $\mathrm{X}$ & $\mathrm{X}$ & $\mathrm{X}$ \\
\hline IDEF & - & - & $\mathrm{X}$ & $\mathrm{X}$ & - & - & $\mathrm{X}$ \\
\hline ORDIT & - & - & $\mathrm{X}$ & $\mathrm{X}$ & $\mathrm{X}$ & $\mathrm{X}$ & - \\
\hline PERA & $\mathrm{X}$ & $\mathrm{X}$ & $\mathrm{X}$ & $\mathrm{X}$ & $\mathrm{X}$ & $\mathrm{X}$ & - \\
\hline SADT & - & - & $\mathrm{X}$ & - & - & - & $\mathrm{X}$ \\
\hline UML & - & - & $\mathrm{X}$ & - & $\mathrm{X}$ & - & $\mathrm{X}$ \\
\hline 4EM & $\mathrm{X}$ & $\mathrm{X}$ & $\mathrm{X}$ & $\mathrm{X}$ & $\mathrm{X}$ & $\mathrm{X}$ & $\mathrm{X}$ \\
\hline
\end{tabular}

We used the 4EM method to model $\mathrm{S}^{\wedge} 3$ Enterprises, since it fully meets a series of requirements that other methods do not contemplate, and considers the aspects highlighted by Berio \& Vernadat (2001) for enterprise modeling.

In previous works, such method has been applied and proved efficient in directing an ERP implementation process from the perspective of innovation networks (Carvalho \& Guerrini, 2017). It identified the changes in the Six Sigma program that are necessary to implement a self-organizing network (Gomes et al., 2017), and helped create a systematic common understanding between automakers and suppliers to promote collaborative management (Guerrini \& Pellegrinotti, 2016).

4EM consists of six models: Goals Model, Business Rules Model, Processes Model, Actors and Resources Model, Technical Requirements and Components Model, and Concepts Model (Bubenko et al., 1998, 2001; Sankuhl et al., 2014). The Goals Model describes the business strategy, focusing on goals and problems to be overcome in order to achieve its purposes. The Business Rules Model sets the rules that control the organization, defining and restricting which actions can be performed to attain the different goals. The Processes Model defines the organizational activities and the way in which processes interact and 
handle information and materials. The purpose of the Actors and Resources Model is to explain who is responsible for a certain process, task or resource. The Components and Technical Requirements Model explains the IT potential for business process improvement, and determines the possible structures and properties of a future information system. The Concepts Model defines entities, attributes, and relationships within the company.

The structure of the 4EM method is presented in Figure 1.

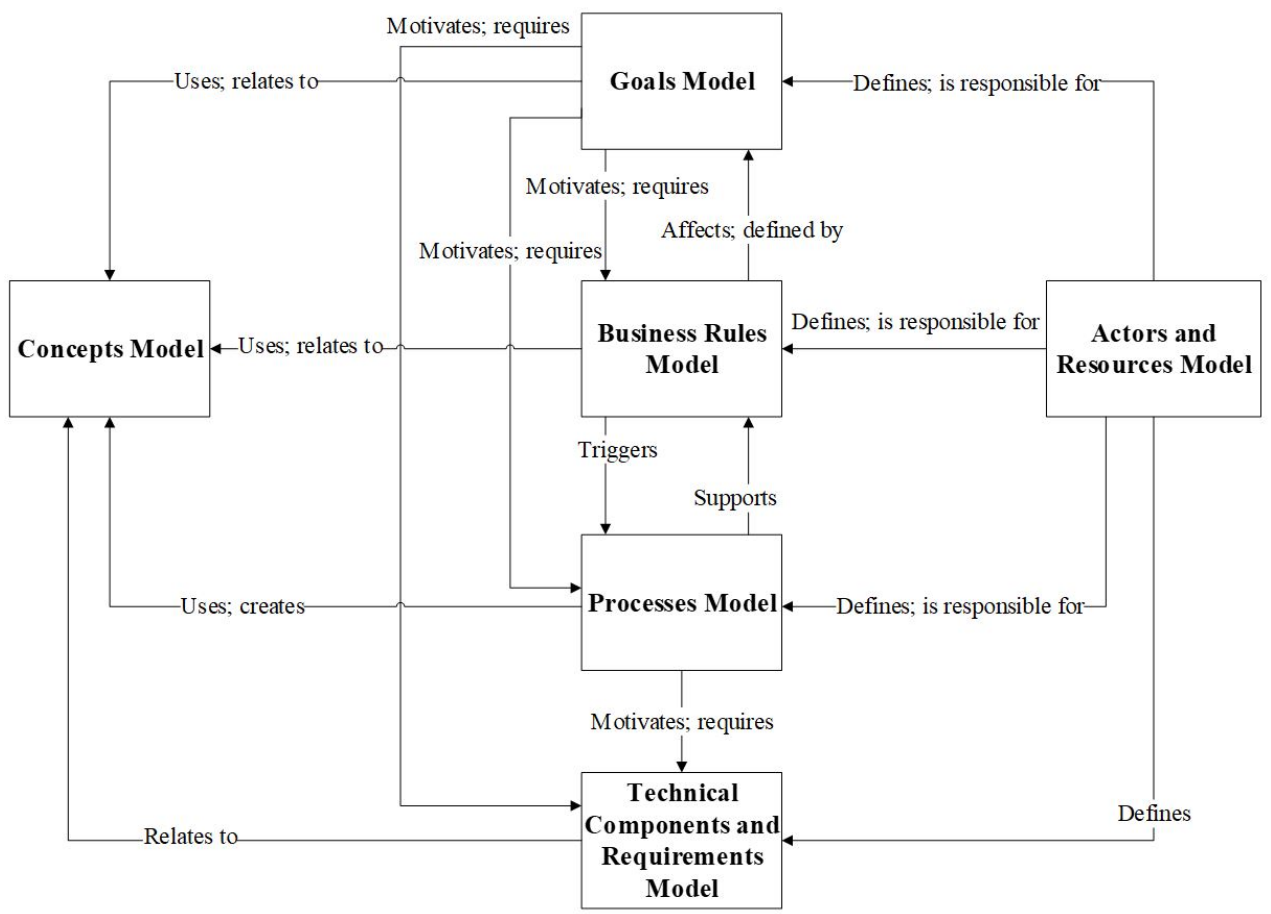

Figure 1. Structure of the 4EM method.

\section{Guiding principles of enterprise modeling}

The current global environment is dynamic and volatile, and requires companies to have adaptability and agility. In this context, cloud computing, big data, service-oriented architecture (SOA), and IT outsourcing models are shifting the infrastructure, IT implementation strategies, data storage, and business models of enterprises (Li et al., 2015).

This paper proposes an enterprise model that associates the $S^{\wedge} 3$ concepts in order to stimulate the application of $S^{\wedge} 3$ systems in enterprises and help their formalization (by providing a large amount of information). According to Weichhart et al. (2016), $S^{\wedge} 3$ concepts are based on eight principles: agility, transparency, empowerment, sharing, collaboration, resilience, innovation, and self-organization. Table 3 presents a description of each principle. 
Table 3. Eight principles of $S^{\wedge} 3$ concepts.

\begin{tabular}{|c|c|}
\hline Principle & Description \\
\hline Agility & $\begin{array}{l}\text { It is temporal concept, associated with the response time and identification of } \\
\text { the cycle of opportunity, configuration, operation/reconfiguration, and dissolution } \\
\text { (Goranson \& Goranson, 1992). }\end{array}$ \\
\hline Transparency & $\begin{array}{l}\text { It aims to ensure access to open information and implement cloud-based } \\
\text { processing to enable community response (Weichhart et al., 2016). }\end{array}$ \\
\hline Empowerment & $\begin{array}{l}\text { It refers to the influence and control of individuals and communities regarding } \\
\text { the decisions that affect them. In general, empowerment is the process by } \\
\text { which people take care of their environment (the physical, economic, social, } \\
\text { cultural, and psychological aspects) employing the resources available } \\
\text { (Fetterman \& Wandersman, 2005). }\end{array}$ \\
\hline $\begin{array}{l}\text { Information, and } \\
\text { knowledge sharing }\end{array}$ & $\begin{array}{l}\text { They encourage innovation and collaboration processes (Weichhart et al., } \\
\text { 2016). }\end{array}$ \\
\hline Collaboration & $\begin{array}{l}\text { It can be described as manifestations of several autonomous and } \\
\text { geographically distributed entities within a heterogeneous operating } \\
\text { environment; the culture, goals, and social capital that collaborate to achieve } \\
\text { better results and common goals. The collaboration among companies is } \\
\text { mentioned in several studies involving collaborative network organizations, } \\
\text { alliances, partnerships, cooperation, and collaborative supply chain, among } \\
\text { others (Camarinha-Matos \& Afsarmanesh, 2008). }\end{array}$ \\
\hline Resilience & $\begin{array}{l}\text { For Luthar et al. (2000), it can be understood as the association of three } \\
\text { essential components: (1) the notion of trauma, adversity, and risk to human } \\
\text { development; (2) the process of positive adaptation and overcoming adversity; } \\
\text { (3) the process that considers the dynamics among emotional, sociocultural, } \\
\text { and cognitive mechanisms that influence the human development. Innovation is } \\
\text { the successful use of new ideas in terms of products, processes, services, and } \\
\text { business practices (Christopherson et al., 2008). }\end{array}$ \\
\hline Self-organization & $\begin{array}{l}\text { This refers to the ability of networks to reorganize themselves into more } \\
\text { heterogeneous structures, and to use more complex processes without a } \\
\text { detailed and centralized management guideline (Kash \& Rycroft, 2002). }\end{array}$ \\
\hline
\end{tabular}

Regarding $S^{\wedge} 3$ Enterprises, Camarinha-Matos et al. (2009) stated that, in order to gain competitive advantage and differentiation, productive organizations have been trying to share skills and resources. This much-desired sharing is based on cooperation networks, and aims to respond quickly to market demands. Enterprise collaboration faces new business requirements because of growing international economic and social integration and the development of ICTs and management models. Musa et al. (2014) pointed out that industrial and service companies of the digital age must be based on distributed and collaborative networks.

For Chavarria-Barrientos et al. (2017), collaborative networks have been identified as a major vehicle for the implementation of the $S^{\wedge} 3$ concept. In a collaborative network, environment knowledge is seen as a critical force towards performance, and sharing such knowledge facilitates timely decision-making (Han \& Park, 2009). Collaborative networks are a way for independent organizations to share essential resources and competencies through partnerships and ICT (Maymand et al., 2012). Collaborative networks are directly linked to the principles of agility, transparency, empowerment, sharing, collaboration, resilience, innovation, and self-organization, since these are the basis for their proper operation. Collaborative networks allow participants to achieve common goals and objectives through interactions that depend on innovation, transparency in sharing information and resources, autonomy for decision-making, and rapid response to the changes in a complex business environment. Integrating these specific sets of capabilities inherent to each network participant allows the development 
of new products, processes or services in a shorter period, and consumes fewer resources (Eschenbächer et al., 2011).

Chavarria-Barrientos et al. (2018) also pointed out that the conception of $S^{\wedge} 3$ Enterprises depends not only on enabling the application of different technologies but also on the development of tools needed to assess and design the enterprise in an integrated way. Weichhart et al. (2016) stated that entrepreneurs have considered enterprise modeling as a new, different method, which may possibly complement existing methods. They have also reinforced that the application of $S^{\wedge} 3$ systems demands a learning and collaboration environment so that benefits and objectives are effectively achieved. The contribution of this paper, therefore, consists in the incorporation of principles related to collaborative networks in the enterprise modeling of $S^{\wedge} 3$ Enterprises, as suggested by Weichhart et al. (2016).

\section{The enterprise model to operationalize $S^{\wedge} 3$ enterprises}

The Concepts, Goals, Business Rules, and Processes models were developed according to interview results and information from the related literature.

\subsection{Concepts Model}

Figure 2 presents the Concepts Model. The guiding principles of $S^{\wedge} 3$ Enterprises are agility, transparency, empowerment, sharing, collaboration, resilience, innovation, and self-organization. $\mathrm{S}^{\wedge} 3$ Enterprises contemplate three systems: sensing, smart, and sustainable. The arrows in Figure 2 describe the formalization steps defined by the 4EM method: there are two filled (black) connectors that link all concepts mentioned above. The three systems integrate, and, together, form the $S^{\wedge} 3$ Enterprises.

The $S^{\wedge} 3$ Enterprise can be considered as a digital company that seeks to face the new challenges imposed by competitive markets. A learning environment is necessary in this context so that efforts effectively bring benefits to the enterprises. Besides a learning environment, teamwork needs flexibility, versatility, creativity, intelligence, and other concepts that are essential to $S^{\wedge} 3$ Enterprises. Companies that systematically encourage the sharing of knowledge and learning at the organizational level reap the benefits of adopting emerging technologies faster (Tortorella et al., 2019).

The sensing system includes the orientation for change (an ideal requirement for the operation of $S^{\wedge} 3$ Enterprises), and is divided into the internal sensing system and the external sensing system. For Jardim-Gonçalves et al. (2016), the internal sensing system has the ability to measure business parameters related to the human behavior and internal performance indicators. Human behavior encompasses parameters such as presence and execution time while internal performance indicators are related to main production processes, management processes, and infrastructure. The external sensing system monitors the environmental parameters associated with external performance indicators, which may vary from one industry to another.

The smart system involves the concepts of human and technological systems and virtual organizations. According to Carvalho \& Schwarzelmüller (2006), human and technological systems refer to the necessary interactions among humans and information systems to ensure the dynamic operation of the system as a whole, since it is people who determine the inclusion of computational resources and technologies and define their applications. The virtual organization represents a set of independent 
organizations that share resources and skills to reach a common goal, not limited to for-profit organizations (Camarinha-Matos \& Afsarmanesh, 2008). In Figure 2, the blank (white) connector linking the aforementioned concepts symbolizes a partial aggregation, that is, it may contain other associated concepts that have not been addressed.

The sustainable system includes the concepts of $3 R$ (reuse, reduction, and recycling), and guidance to consumers. The first refers to environmental aspects and the second to economic and social aspects, as explained in previous sections. Different architectures and languages are dismembered into the enterprise architecture and SOA and tied to the sustainable system. They serve as support for sustainability. Architecture is a description of the basic arrangement and connectivity of the parts of a system, and usually has several meanings, depending on its use. Architectures can represent the formal description of a system at the component level to guide its implementation; or describe the structure of components, their interrelationships, principles, and guidelines that govern their design and evolution over time; or yet describe the organizational structure of a system or component (Chen et al., 2008).

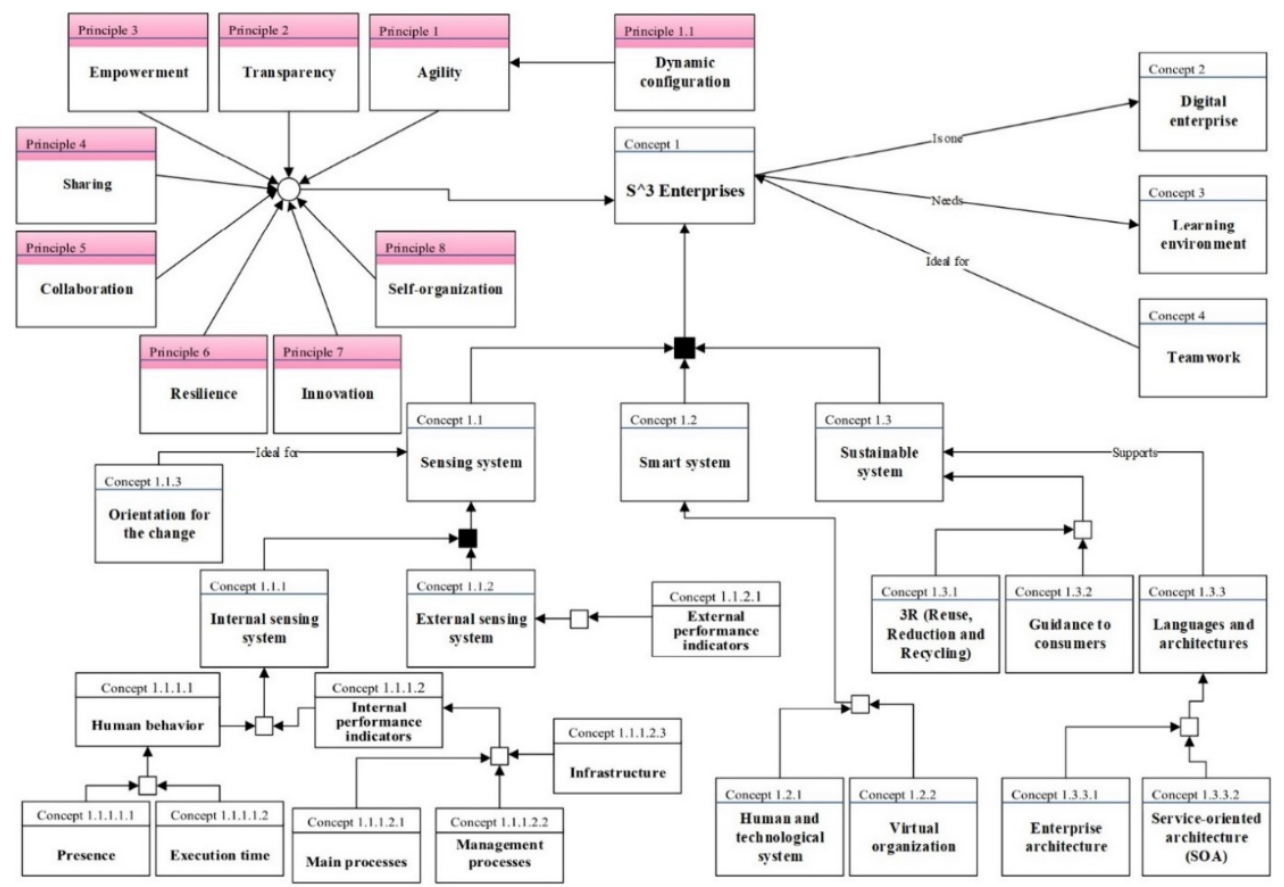

Figure 2. Concepts Model.

\subsection{Goals Model}

Figure 3 presents the Goals Model. The main goal of $S^{\wedge} 3$ Enterprises is to stimulate the application of $S^{\wedge} 3$ systems, directly supported by two objectives: to strengthen competitiveness and to process a great amount of information. The $S^{\wedge} 3$ system seeks to stimulate sensing, smart, and sustainable philosophies, creating mechanisms that stimulate innovation and ensure collaboration, cooperation, and a holistic view of the enterprise. 
To stimulate the application of $S^{\wedge} 3$ systems one must pay attention to threats to the business environment, such as conceptual, organizational, and technological barriers. The successful application of $S^{\wedge} 3$ systems allows for improved decision-making, and digital competences.

The literature mentions some barriers to be addressed, such as collaborative models to support human-machine interaction (Tan et al., 2009), compatibility between systems, interfaces and networks (Leitão et al., 2016; Elkhodr et al., 2016), so that wireless technologies and sensors can interact with the physical world (Elkhodr et al., 2016, Rajput \& Singh, 2019), digitization and process automation (Schumacher et al., 2016, Rajput \& Singh, 2019), virtualization of the automation system (Babiceanu \& Seker, 2016; Rajput \& Singh, 2019), and data analysis (Tan et al., 2009), since a large amount of data captured in different formats must be analyzed to provide reliable information to support decision-making.

To implement a smart philosophy it is necessary to focus on some constraints such as organizational inertia, existing assets, job protection, preservation of legacy systems, customer-buyer relationships, inefficient and costly methodologies and logistics infrastructure, and lack of standardized data formats. It is also important to emphasize industrial replication, a complex problem that can arise through interactions with competitors, when companies learn and adapt to the actions of others (Musa et al., 2014). According to Kim et al. (2015), the successful implementation of a smart philosophy generates improved resource efficiency, strengthens network resilience, and facilitates integration among the shop floor, all the different enterprise units, and the supply chain. Hofmann \& Rüsch (2017) reinforce that such a philosophy provides significant gains in inter-organizational logistics, particularly regarding real-time information flows, end-to-end supply chain transparency, and flexibility in the implementation of improvements. It all results in the creation of value.

Bhanot et al. (2017) pointed out that to implement a sustainable philosophy it is necessary to overcome some constraints, such as the lack of financial incentive (resources destined to the development of sustainable products) and credit (resources provided by banking institutions). It is also important to highlight the lack of metrics for evaluating the sustainable performance of organizations, the lack of support from enterprise management, and the high costs involved in implementing sustainable initiatives (Bhanot et al., 2017, Ramani et al., 2017). It is essential to pay special attention to the support from enterprise management since, according to Chiu (2015), the sustainable enterprise vision can only be realized if it is part of the business planning and decision-making at the top level. 


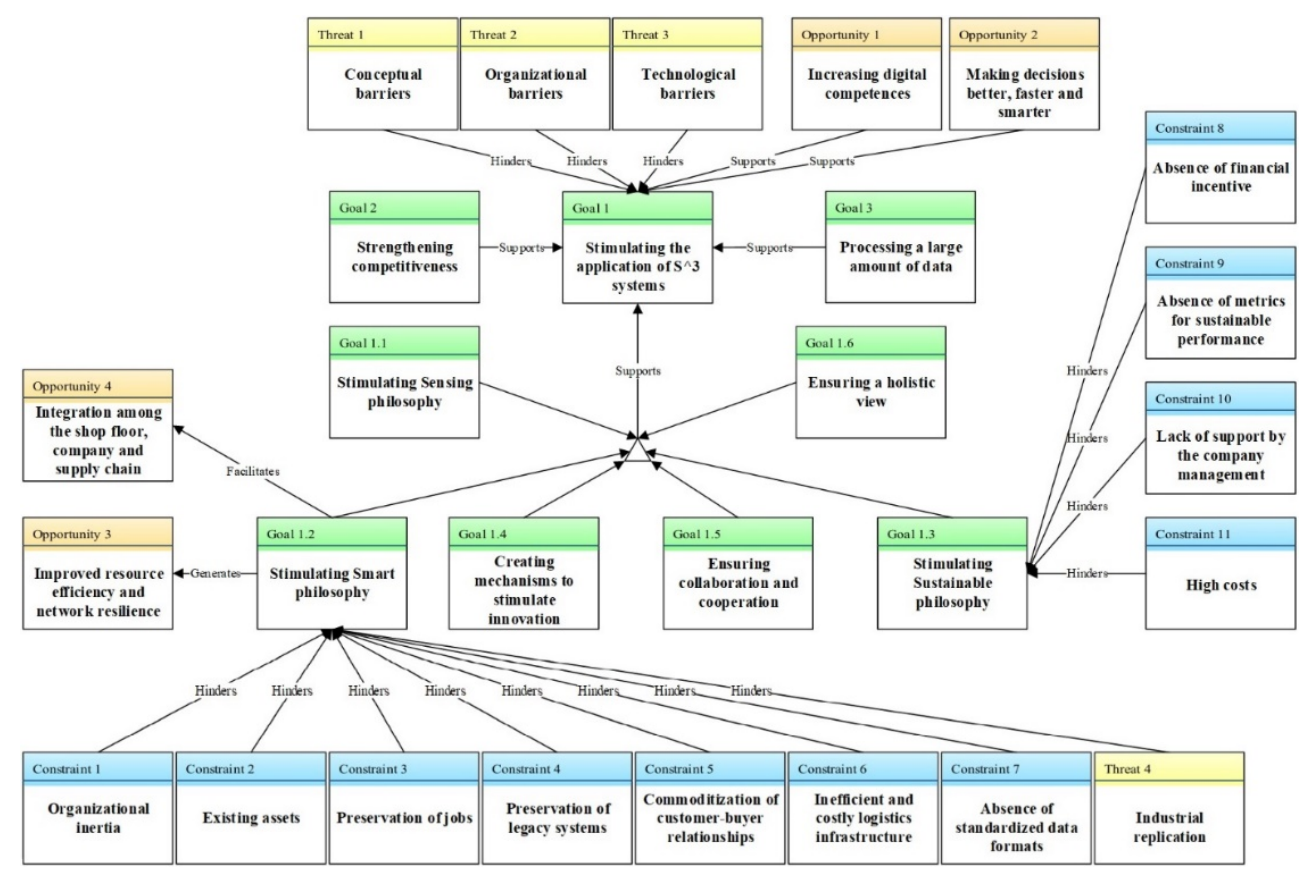

Figure 3. Goals Model.

\subsection{Business Rules Model}

Figure 4 presents the Business Rules Model. Periodic investments in intellectual assets for constant development of knowledge are necessary to strengthen enterprise competitiveness. The processing of large amounts of information requires the strategic use of ICTs for real-time information gathering, integrated ICT platforms, and constant adaptation to the increase in transaction volume.

The sensing philosophy requires the use of convergent IT and dynamism to meet market expectations. The smart philosophy can be implemented through the continuous use of intelligent services. The sustainable philosophy requires the constant incorporation of self-organizing elements. The participation of industry members in conferences and seminars organized by universities and government agencies is very important for stimulating sustainable philosophy (Bhanot et al., 2017). Environmental conferences and seminars highlight the constraints that hinder the achievement of sustainable development, locally driven environmental programs, and market awareness in relation to sustainable products.

The creation of mechanisms to stimulate innovation requires the continuous reappraisal of traditional paradigms and continuous search of actors within complementary cognitive distances. To ensure collaboration and a holistic view of the enterprise, it is crucial to invest in Research and Development (R\&D) throughout the product life cycle. Such an investment requires the involvement of stakeholders, the development of a supply chain overview, and the systematic monitoring of the product development process. Periodic audits are needed to ensure that the $S^{\wedge} 3$ system is fully effective and all associated goals have been achieved.

The strategic use of ICTs for real-time information gathering and the use of efficient algorithms are necessary for the application of the different systems. For Wu et al. (2017), smart manufacturing companies (including the $S^{\wedge} 3$ Enterprises) established in 
collaborative environments must have ICT systems that instantly collect and analyze information generated in machines and industrial processes. Algorithms that efficiently diagnose the root cause of identified defects and maintenance activities required to minimize unplanned downtime are other crucial requirements of intelligent manufacturing (Wu et al., 2017).

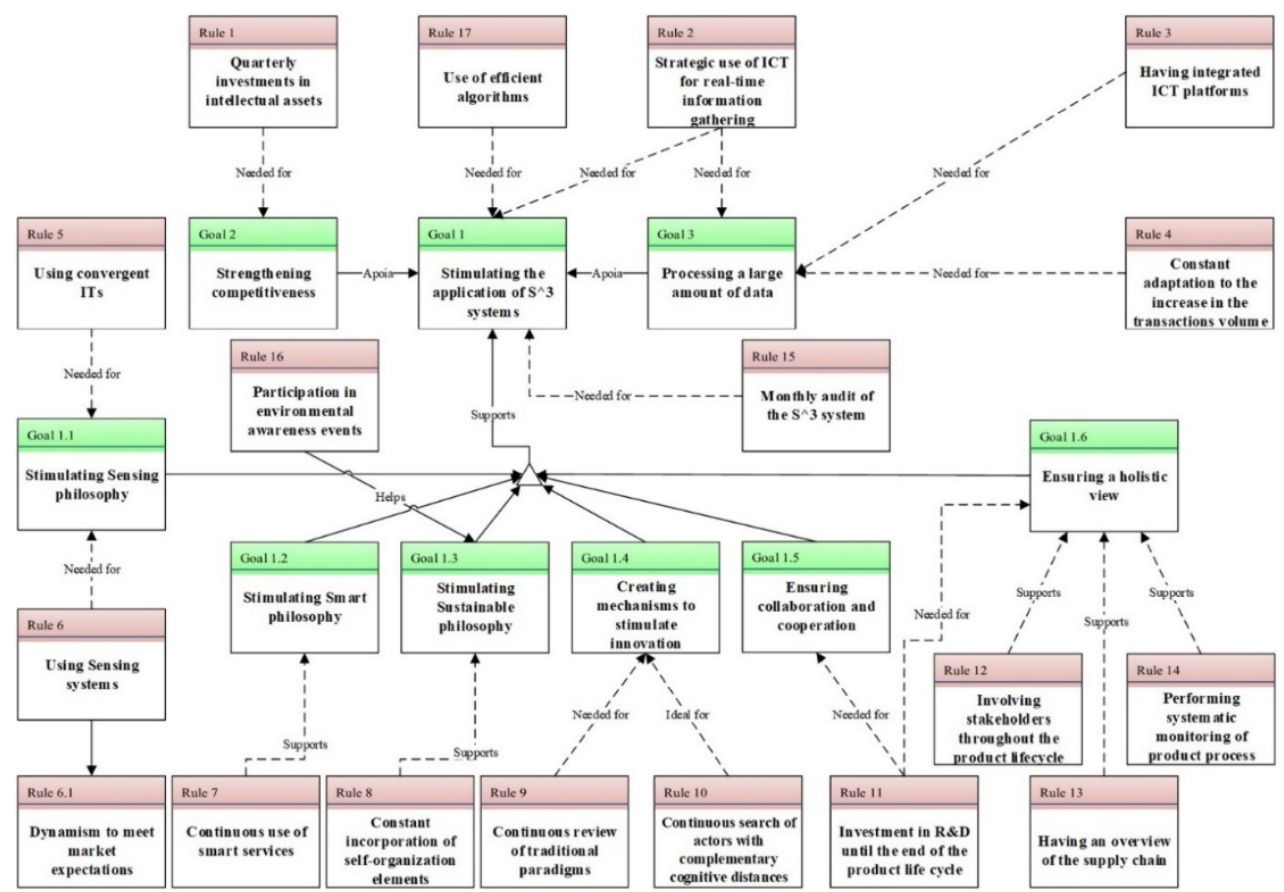

Figure 4. Business Rules Model.

\subsection{Processes Model}

The Processes Model of the 4EM interacts with the Goals, Business Rules, Actors and Resources, and Technical Components and Requirements models. Figure 5 illustrates the Processes Model of $S^{\wedge} 3$ Enterprises. Dashed lines indicate interfaces among elements of the different 4EM sub-models.

The development of a $S^{\wedge} 3$ system is supported by the stimulus to implement sensing, smart, and sustainable philosophies, the gathering of multidimensional information, the presence of proactivity and agility in decision-making, the adaptability to different market needs, the creation and exploitation of knowledge, the responsiveness to the opportunities of the digital age, and the optimization of plant operations (supported by a best practices bank). The type of professional involved in the development of $S^{\wedge} 3$ Enterprises is not widely defined; the literature points to industrial engineers, IT analysts, marketing experts, and experts in e-services.

The process of $S^{\wedge} 3$ system development needs the establishment of collaborative links for innovation transfer, thus it is necessary to develop dedicated business areas to handle the seeking of new partnerships (Stanescu et al., 2013). Mauricio-Moreno et al. (2015) pointed out a lack of understanding in communication processes as a major problem among multidisciplinary teams. Critical decisions should be made quickly and concurrently with the sharing of skills and resources. 
Continuous use of intelligent services requires $\mathrm{CNC}$, industrial robots, smart sensors, enhanced tags, intelligent agents, telephones, video cameras, appliances with multiple sensors or smart objects to provide continuous awareness and improvement of business operations in a digital environment. Integrated ICT platforms, converging ITs, and ICT for real-time information gathering are necessary for the successful operation of an $S^{\wedge} 3$ system, since companies need to continuously negotiate, create, and maintain interoperability with their partners (a global knowledge of business systems) in order to align inter-organizational goals. The alignment of inter-organizational goals helps define where business processes will be implemented and possible partners, as well as their competences and resources.

The constant adaptation to the increasing volume of transactions and the incorporation of self-organization elements promotes the adaptation and flexibility necessary for developing customized products and services, essential in the context of intelligent manufacturing. Chavarria-Barrientos et al. (2016) stated that mass customization is a strong trend in $S^{\wedge} 3$ Enterprises. In this context, it is a great challenge to satisfy customer specific requirements, since production volumes should be low and flexible, the variety of products should be large, and heterogeneous demand patterns arising from dissimilar niches, low cost and high-quality expectations, and short product life cycles should be addressed. Technologies like PLC, WSN, CRM, and SRM provide the flexibility needed to achieve a Build To Order production system based on a collaborative network (Chavarria-Barrientos et al., 2016).

Monitoring of the external and internal environments of the enterprise allows it to become context-aware of its global context (facilities, consumers, social networks, markets, competition). The monitoring of internal environment implies the monitoring of physical or environmental conditions such as temperature, sound, vibration, pressure, motion, etc., while the monitoring of external environment implies the anticipation of trends from consumers, markets, and competitors. An $S^{\wedge} 3$ Enterprise should be proactive (able to anticipate and to act in timely manner) in order to increase its incomes and productivity and to avoid dangerous situations.

The reduction of productive inputs and the improvement of products to minimize environmental impacts involve the application of manufacturing good practices, the reduction in volume of hazardous materials and raw material in general, the elimination/reduction of waste, and the efficient use of energy and materials. This should be implemented without compromising customer satisfaction. Techniques and tools such as Eco-design, Design For Environment (DFE), and Life-Cycle Assessment (LCA) can be applied to enable the structuring of metrics to evaluate environmental performance. 


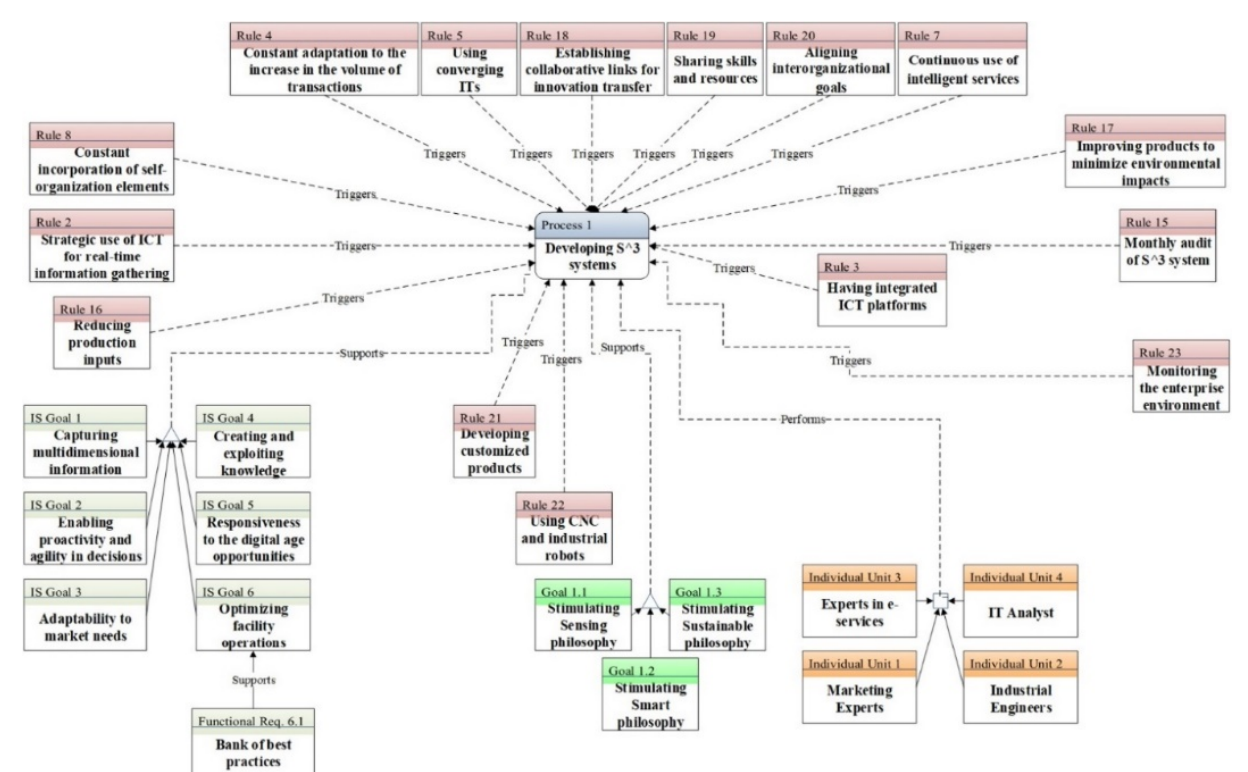

Figure 5. Processes Model.

\section{Discussion of results}

Weichhart et al. (2016) presented the concept, challenges, and current developments in $S^{\wedge} 3$ enterprise systems. They have suggested some gaps to be addressed by future studies within the enterprise modeling scope, with special focus on the concept integration of enterprise models with other business methods, the use of common and simpler languages to facilitate the understanding of models, and the involvement of enterprise modeling in collaborative environments.

The concept of $S^{\wedge} 3$ Enterprises was created to address ICT advancements, growing market dynamism, and high competitiveness, and we searched in the literature its concepts, basic and associated activities to properly construct enterprise models that can serve as a reference for organizations interested in applying the $S^{\wedge} 3$ philosophy in their practices. The construction of the models presented in Section 5 was based on a literature review and subsequent interview with a manufacturing professional.

Enterprise modeling stands out as the main method to present company knowledge, since it is supported by the modeling of company structure, organization, and performance. Modeling techniques ensure access to the enterprise knowledge needed to perform process improvements, interoperability, integration, coordination, and decision-making between companies (De La Fuente et al., 2010).

The bureaucratic dysfunction of organizations becomes part of the computerization process. When business processes are digitized with bureaucratic dysfunctions, the problem is formalized in the system and will keep recurring.

The following results were obtained with the application of the 4EM methodology:

- The main definitions of The Concepts Model for $S^{\wedge} 3$ Enterprises (sensing, smart, and sustainable systems) were presented, along with its principles (agility, transparency, empowerment, sharing, collaboration, resilience, innovation, and self-organization), the supporting concepts (architectures and languages) and requirements (orientation for change, teamwork, and learning environment); 
- The Goals and Business Rules Model was presented as encompassing the main goals of $S^{\wedge} 3$ Enterprises, the opportunities found within this new business paradigm, and the threats that hinder these opportunities. It also contains guidelines that indicate the main considerations to be analyzed during formalization. They are closely related to goals and processes;

- The Processes Model associates goals, rules, actors, technical components, and requirements. However, due to the lack of sufficient information, it was not possible to present in detail the main activities carried out for the formalization of $S^{\wedge} 3$ Enterprises in this model. Nonetheless, it was possible to observe the main rules starting each necessary process and the actors performing key activities, as well as the information system goals and functional requirements that support certain processes.

Such models can guide companies in analyzing, designing, reengineering, restructuring, integrating, optimizing, monitoring, and controlling their manufacturing and supply chain systems, driving the change toward $S^{\wedge} 3$ Enterprises.

Enterprise modeling assists in capturing organizational requirements for information system development. It implements the To-Be state, in which processes are redesigned and aligned with organizational objectives.

Some considerations are crucial to ensure the effectiveness of the enterprise model:

- Modeling primarily depends on the involvement of the people who are part of the organization;

- Modeling is a comprehensive concept that offers different approaches, techniques, and methods. Understanding the fundamentals and their applications creates a high-level discussion of what is essential in modeling;

- The different modeling perspectives must complement and complete each other to ensure the effectiveness of the enterprise model.

\section{Conclusions}

Nowadays, with the constant changes in society, it has become increasingly necessary to invest in new technologies and tools, which in turn reinforces the need for a new enterprise paradigm to meet future digital trends. Global social problems, increasing competition, market uncertainties, and recent advances in the manufacturing industry are pushing enterprises to adopt new strategies that allow them to face these challenges and remain competitive in the marketplace.

This study presented concepts related to $S^{\wedge} 3$ Enterprises whose goals are directly related to meeting new market trends and needs. $S^{\wedge} 3$ Enterprises are marked by continuous monitoring of their context and operation (sensing), possible smart decision-making when creating collaborative networks that enhance their reactive and proactive capabilities (smart), and use of their technological and human resources to become sustainable in the environmental, economic, and social aspects (sustainable).

Through a literature review and consultation with a specialist in the field, this study sought to provide an overview of the sensing, smart, and sustainable concepts, with the purpose of developing enterprise models based on the 4EM method. Thus the models presented an initial view of the main requirements necessary for the formalization of $S^{\wedge} 3$ Enterprises. These models also allow researchers, entrepreneurs, and other parties interested in the development of such organizations to analyze them from other perspectives. 


\subsection{Practical and scientific contributions of the research}

The enterprise model is an initial step towards the construction of a formal and well-recognized framework of $S^{\wedge} 3$ Enterprises. Several challenges and requirements have been introduced to guide and promote research related to this area of study. The main practical and scientific contributions of this paper were:

- Providing stakeholders with an overview of $S^{\wedge} 3$ Enterprises, its foundations, concepts, and expected goals, as well as the processes and rules necessary for its execution;

- Representing $\mathrm{S}^{\wedge} 3$ Enterprises in an enterprise model that was developed and systematized with the Concepts, Goals, Business Rules, and Processes models of the 4EM method. Such representation allows further analysis and orientation from different perspectives;

- Contributing with the literature regarding $S^{\wedge} 3$ Enterprises by filling research gaps identified in previous works, and presenting a new analytical approach for such organizations;

- Systematizing principles related to collaborative networks in the $S^{\wedge} 3$ Enterprises approach.

The information presented in this research is in accordance with the orientation of Molina et al. (2014), since it allows the identification of the enterprise requirements in supporting the $S^{\wedge} 3$ concepts, and also helps the design and implementation of the $S^{\wedge} 3$ system itself by presenting principles, tools, challenges, and benefits.

Regarding the development of the Processes Model, despite the difficulty in modeling the processes to the point of identifying specific steps, high-level modeling creates an understanding of how some rules, goals, actors, and principles correlate to the processes.

\subsection{Critical positioning}

To be successful, enterprises must implement the sensing, smart, and sustainable concepts, not only in managing their operations, but also in developing their products, services, and manufacturing processes. The development of systems that adopt these concepts will have a great positive impact on improving the quality of life in society.

We propose that collaborative networks have been identified as a major vehicle for consolidation of $S^{\wedge} 3$ Enterprises. Collaboration is an inherent principle of the $\mathrm{S}^{\wedge} 3$ Enterprises, since the definition of its domain, and the use of enterprise modeling as language, creates a clearer understanding of the relationship among companies. A collaborative network enables the use of multiple core competencies, ensuring the flexibility needed to deliver customized products and services, with quality and a fast development cycle.

The sensing concept is shifting focus towards a borderless enterprise, having requirements such as collaboration, agility, teamwork, adaptability, flexibility, proactivity, self-organization, interoperability, continuous interactions among smart objects and systems, continuous awareness and improvement of business operations, and good communication channels.

The smart characteristic of an $S^{\wedge} 3$ Enterprise can be implemented using machine-to-machine communication among embedded processors, smart actuators, smart sensors, and terminal devices with or without human intervention. 
The literature points to the implementation of smart processes, products, and services that can be found in different domains, especially in automotive systems, medical devices, assisted living, traffic control and safety, process control, energy conservation, environmental control, robotics, instrumentation, critical infrastructure control, defense systems, and high-tech manufacturing. However, a great challenge in implementing smart systems is the possible incorrect interpretation of data by computers, machines, and sensors. This problem is caused by the several possible interpretations of readers and cannot be solved by simply increasing equipment accuracy.

The sustainability in $S^{\wedge} 3$ Enterprises is not limited to environmental aspects. This question involves environmental, social, and economic issues. The environmental issues involve the reduction of environmental impacts through the efficient use of materials, energy, and good manufacturing processes. The social issues are related to the contribution of the enterprise to the quality of life in its community, considering aspects such as health, education, culture, and housing. The economic issues are related to productivity, development of low-cost products, the birth of other enterprises, employment generation and profitability, among other benefits. We believe that, when it comes to the sustainability of an $S^{\wedge} 3$ Enterprise, emissions, pollution, resource consumption, and natural habitat conservation are some of the main indicators of the environmental issues; cost, profit, and investment measure the economic aspect; and the level of satisfaction of employees, customers, and the community guides the social aspect.

\subsection{Limitations of the approach and future research}

First, it is important to point out that not all steps defined by the 4EM method were followed. The method reinforces the need to gather a group of people to perform enterprise modeling for the process in question. This, however, did not occur, since $\mathrm{S}^{\wedge} 3$ Enterprises are still a future perspective, and, consequently, there are not many experts in the field with consolidated knowledge to provide consistent information.

Another important limiting factor to be mentioned is the fact that there are few papers addressing this subject in the extant literature, and few market professionals with experience and knowledge in this new industrial approach. This complicates the acquisition of consolidated data and information. Such limiting factors prevented the presentation of a broad and consistent Process Model.

Since $S^{\wedge} 3$ Enterprises have not been properly formalized yet, the models for Actors and Resources and Technical Components and Requirements of the 4EM method were not developed. Future research should thoroughly examine the main agents and supporting information systems of these organizations to incorporate them into the above-mentioned enterprise models of the 4EM and link them to the other models presented in this paper. The correct interpretation of data by computers and sensors represents an important requirement to be incorporated in supporting information systems, and, consequently, in future Technical Components and Requirements Models.

Another suggestion for future works is the presentation of case studies applying the models developed in this work, since, according to Voss et al. (2002), this is the most appropriate research method to conduct investigations in which experience is rare and contextual conditions are unknown. Runfola et al. (2017) also concur that case study offers the opportunity to understand a phenomenon that is particularly important in the field of management. We expect that the adoption and consolidation of the $S^{\wedge} 3$ 
approach in enterprises will provide the practical information necessary for the development of this research topic, providing appropriate reference modeling (Cretan et al., 2012).

\section{References}

Agostinho, C., \& Jardim-Gonçalves, R. (2015). Sustaining interoperability of networked liquidsensing enterprises: a complex systems perspective. Annual Reviews in Control, 39, 128143. http://dx.doi.org/10.1016/j.arcontrol.2015.03.012.

Almada-Lobo, F. (2015). The Industry 4.0 Revolution and the Future of Manufacturing Execution Systems (MES). Journal of Innovation Management, 3(4), 16-21. http://dx.doi.org/10.24840/2183-0606_003.004_0003.

Babiceanu, R. F., \& Seker, R. (2016). Big data and virtualization for manufacturing cyberphysical systems: A survey of the current status and future outlook. Computers in Industry, 81, 128-137. http://dx.doi.org/10.1016/j.compind.2016.02.004.

Berio, G., \& Vernadat, F. (2001). Enterprise modelling with CIMOSA: functional and organizational aspects. Production Planning and Control, 12(2), 128-136. http://dx.doi.org/10.1080/09537280150501239.

Bertoni, M., Bordegoni, M., Cugini, U., Regazzoni, D., \& Rizzi, C. (2009). PLM paradigm: How to lead BPR within the Product Development field. Computers in Industry, 60(7), 476-484. http://dx.doi.org/10.1016/j.compind.2009.02.004.

Bhanot, N., Rao, P. V., \& Deshmukh, S. G. (2017). An integrated approach for analysing the enablers and barriers of sustainable manufacturing. Journal of Cleaner Production, 142(Pt 4), 4412-4439. http://dx.doi.org/10.1016/j.jclepro.2016.11.123.

Braha, D., Stacey, B., \& Bar-Yam, Y. (2011). Corporate competition: a self-organized network. Social Networks, 33(3), 219-230. http://dx.doi.org/10.1016/j.socnet.2011.05.004.

Brodsky, A., Shao, G., Krishnamoorthy, M., Narayanan, A., Menascé, D., \& Ronay, A. (2017). Analysis and optimization based on reusable knowledge base of process performance models. International Journal of Advanced Manufacturing Technology, 88(1-4), 337-357. http://dx.doi.org/10.1007/s00170-016-8761-7. PMid:31274946.

Bubenko, J., Brash, D., \& Stirna, J. (1998). EKD user guide. ELEKTRA: Electrical Enterprise Knowledge for Transforming Applications (Project No. 22927). China: Elektra consorium.

Bubenko, J., Persson, A., \& Stirna, J. (2001). EKD D3: User guide of the knowledge management approach using enterprise knowledge patterns (Hyperknowledge IST-200028401). China: Elektra consorium.

Busquets, J., Rodon, J., \& Wareham, J. (2009). Adaptability in smart business networks: an exploratory case in the insurance industry. Decision Support Systems, 47(4), 287-296. http://dx.doi.org/10.1016/j.dss.2009.05.006.

Camarinha-Matos, L. M., \& Afsarmanesh, H. (2007). A comprehensive modeling framework for collaborative networked organizations. Journal of Intelligent Manufacturing, 18(5), 529-542. http://dx.doi.org/10.1007/s10845-007-0063-3.

Camarinha-Matos, L. M., \& Afsarmanesh, H. (2008). On reference models for collaborative networked organizations. International Journal of Production Research, 46(9), 2453-2469. http://dx.doi.org/10.1080/00207540701737666.

Camarinha-Matos, L. M., Afsarmanesh, H., Galeano, N., \& Molina, A. (2009). Collaborative networked organizations: concepts and practice in manufacturing enterprises. Computers \& Industrial Engineering, 57(1), 46-60. http://dx.doi.org/10.1016/j.cie.2008.11.024.

Camarinha-Matos, L. M., Fornasiero, R., \& Afsarmanesh, H. (2017). Collaborative networks as a core enabler of industry 4.0. IFIP Advances in Information and Communication Technology, 506, 3-17. http://dx.doi.org/10.1007/978-3-319-65151-4_1. 
Carvalho, H. L., \& Guerrini, F. M. (2017). Reference model for implementing ERP systems: an analytical innovation networks perspective. Production Planning and Control, 28(4), 281294. http://dx.doi.org/10.1080/09537287.2016.1273409.

Carvalho, K. D., \& Schwarzelmüller, A. F. (2006). O humano e o tecnológico nas organizações: tecnologia multimídia: um novo instrumento de conhecimento. Tempo Brasileiro, 165, 159181.

Cervo, A. L., Bervian, P. A., \& Silva, R. (2007). Metodologia científica (6. ed.). São Paulo: Pearson Prentice Hall.

Chardine-Baumann, E., \& Botta-Genoulaz, V. (2014). A framework for sustainable performance assessment of supply chain management practices. Computers \& Industrial Engineering, 76, 138-147. http://dx.doi.org/10.1016/j.cie.2014.07.029.

Chavarria-Barrientos, D., Batres, R., Perez, R., Wright, P. K., \& Molina, A. (2016). A step towards customized product realization: methodology for Sensing, Smart and Sustainable Enterprise. IFIP Advances in Information and Communication Technology, 480, 327-339. http://dx.doi.org/10.1007/978-3-319-45390-3_28.

Chavarria-Barrientos, D., Batres, R., Wright, P. K., \& Molina, A. (2018). A methodology to create a sensing, smart and sustainable manufacturing enterprise. International Journal of Production Research, 56(1-2), 584-603. http://dx.doi.org/10.1080/00207543.2017.1386333.

Chavarria-Barrientos, D., Camarinha-Matos, L. M., \& Molina, A. (2017). Achieving the sensing, smart and sustainable "everything". In L. M. Camarinha-Matos, H. Afsarmanesh \& R. Fornasiero (Eds.), Collaboration in a Data-Rich World. PRO-VE 2017. IFIP Advances in Information and Communication Technology. Cham: Springer. http://dx.doi.org/10.1007/978-3-319-65151-4_51.

Chen, D., Doumeingts, G., \& Vernadat, F. (2008). Architectures for enterprise integration and interoperability: past, present and future. Computers in Industry, 59(7), 647-659. http://dx.doi.org/10.1016/j.compind.2007.12.016.

Chiu, Y. L. A. (2015). Towards sustainable enterprises: the impact factor of climate change for corporate responsibility and performance. European Journal of Law and Economics, 40(2), 341-365. http://dx.doi.org/10.1007/s10657-012-9364-x.

Christopherson, S., Kitson, M., \& Michie, J. (2008). Innovation, networks and knowledge exchange. Cambridge Journal of Regions, Economy and Society, 1(2), 165-173. http://dx.doi.org/10.1093/cjres/rsn015.

Cortés, D., Ramírez, J., Villagómez, L. E., Batres, R., Molina, A., Velilla, A., Lozano, G., González, E., Puente, J., Esparza, G., \& Cruz, N. (2019). A model for plant digitalisation, simulation and improvement: a case study in the automotive tier one supplier. In Proceedings of the 2019 IEEE International Conference on Engineering, Technology and Innovation (ICE/ITMC) (pp. 1-6). USA: IEEE. http://dx.doi.org/10.1109/ICE.2019.8792664.

Cretan, A., Coutinho, C., Bratu, B., \& Jardim-Goncalves, R. (2012). NEGOSEIO: a framework for negotiations toward sustainable enterprise interoperability. Annual Reviews in Control, 36(2), 291-299. http://dx.doi.org/10.1016/j.arcontrol.2012.09.010.

Daaboul, J., Castagna, P., Cunha, C., \& Bernard, A. (2014). Value network modelling and simulation for strategic analysis: a discrete event simulation approach. International Journal of Production Research, 52(17), 5002-5020. http://dx.doi.org/10.1080/00207543.2014.886787.

Davis, J., Edgar, T., Porter, J., Bernaden, J., \& Sarli, M. (2012). Smart manufacturing, manufacturing intelligence and demand-dynamic performance. Computers \& Chemical Engineering, 47, 145-156. http://dx.doi.org/10.1016/j.compchemeng.2012.06.037.

De La Fuente, M. V., Ros, L., \& Ortiz, A. (2010). Enterprise modelling methodology for forward and reverse supply chain flows integration. Computers in Industry, 61(7), 702-710. http://dx.doi.org/10.1016/j.compind.2010.05.010. 
Elkhodr, M., Shahrestani, S., \& Cheung, H. (2016). The internet of things: new interoperability, management and security challenges. International Journal of Network Security \& Its Applications, 8(2), 85-102. http://dx.doi.org/10.5121/ijnsa.2016.8206.

Eschenbächer, J., Seifert, M., \& Thoben, K. D. (2011). Improving distributed innovation processes in virtual organisations through the evaluation of collaboration intensities. Production Planning and Control, 22(5-6), 473-487. http://dx.doi.org/10.1080/09537287.2010.536620.

Ferro-Beca, M. D., Sarraipa, J., Agostinho, C., Gigante, F., Jose-Nunez, M., \& JardimGoncalves, R. (2015). A framework for enterprise context analysis based on semantic principles. Computer Science and Information Systems, 12(3), 931-960. http://dx.doi.org/10.2298/CSIS150105037F.

Fetterman, D. M., \& Wandersman, A. (2005). Empowerment evaluation: principles in practice. New York: The Guilford Press.

Filos, E. (2006). Smart organizations in the digital age. In I. Mezgar (Ed.), Integration of ICT in smart organizations. London: Idea Group Publishing. http://dx.doi.org/10.4018/978-159140-390-6.ch001.

Gomes, L. P. C., Marques, D. M. N., \& Guerrini, F. M. (2017). Self-organizing Six Sigma Program: as-is model and need for changes. Gestão \& Produção, 24(1), 95-107. http://dx.doi.org/10.1590/0104-530x1506-15.

Goranson, H. T., \& Goranson, T. (1992). The agile virtual enterprise: cases, metrics, tools. Westport: Quorum Books.

Guerrini, F. M., \& Pellegrinotti, C. C. (2016). Reference model for collaborative management in the automotive industry. Production Planning and Control, 27(3), 183-197. http://dx.doi.org/10.1080/09537287.2015.1091518.

Han, K. H., \& Park, J. W. (2009). Process-centered knowledge model and enterprise ontology for the development of knowledge management system. Expert Systems with Applications, 36(4), 7441-7447. http://dx.doi.org/10.1016/j.eswa.2008.09.031.

Hofmann, E., \& Rüsch, M. (2017). Industry 4.0 and the current status as well as future prospects on logistics. Computers in Industry, 89, 23-34. http://dx.doi.org/10.1016/j.compind.2017.04.002.

Jardim-Gonçalves, R., Grilo, A., \& Popplewell, K. (2016). Novel strategies for global manufacturing systems interoperability. Journal of Intelligent Manufacturing, 27(1), 1-9. http://dx.doi.org/10.1007/s10845-014-0948-x.

Jia, S., Tang, R., \& Lv, J. (2016). Machining activity extraction and energy attributes inheritance method to support intelligent energy estimation of machining process. Journal of Intelligent Manufacturing, 27(3), 595-616. http://dx.doi.org/10.1007/s10845-014-0894-7.

Kash, D. E., \& Rycroft, R. (2002). Emerging patterns of complex technological innovation. Technological Forecasting and Social Change, 69(6), 581-606. http://dx.doi.org/10.1016/S0040-1625(01)00171-8.

Kassem, M., Dawood, N. N., \& Mitchell, D. (2011). A structured methodology for enterprise modeling: a case study for modeling the operation of a british organization. Journal of Information Technology in Construction, 16, 381-410.

Kim, D. B., Denno, P. O., \& Jones, A. T. (2015). A model-based approach to refine process parameters in smart manufacturing. Concurrent Engineering, Research and Applications, 23(4), 365-376. http://dx.doi.org/10.1177/1063293X15591038.

Lakhoua, M. N., \& Rahmouni, M. (2011). Investigation of the methods of the enterprise modeling. African Journal of Business Management, 5(16), 6845-6852.

Lee, Y. S., \& Chung, S. H. (2016). An efficient distributed scheduling algorithm for mobility support in IEEE 802.15. 4e DSME-based industrial wireless sensor networks. International 
Journal of Distributed Sensor Networks, 12(2), 1-14.

http://dx.doi.org/10.1155/2016/9837625.

Leitão, P., Colombo, A. W., \& Karnouskos, S. (2016). Industrial automation based on cyberphysical systems technologies: prototype implementations and challenges. Computers in Industry, 81, 11-25. http://dx.doi.org/10.1016/j.compind.2015.08.004.

Li, Q., Luo, H., Xie, P. X., Feng, X. Q., \& Du, R. Y. (2015). Product whole life-cycle and omnichannels data convergence oriented enterprise networks integration in a sensing environment. Computers in Industry, 70, 23-45. http://dx.doi.org/10.1016/j.compind.2015.01.011.

Liu, M., Ma, J., Lin, L., Ge, M., Wang, Q., \& Liu, C. (2017). Intelligent assembly system for mechanical products and key technology based on internet of things. Journal of Intelligent Manufacturing, 28(2), 271-299. http://dx.doi.org/10.1007/s10845-014-0976-6.

Luthar, S. S., Cicchetti, D., \& Becker, B. (2000). The construct of resilience: a critical evaluation and guidelines for future work. Child Development, 71(3), 543-562. http://dx.doi.org/10.1111/1467-8624.00164. PMid:10953923.

Marques, M., Agostinho, C., Zacharewicz, G., \& Jardim-Gonçalves, R. (2017). Decentralized decision support for intelligent manufacturing in Industry 4.0. Journal of Ambient Intelligence and Smart Environments, 9(3), 299-313. http://dx.doi.org/10.3233/AIS-170436.

Mauricio-Moreno, H., Miranda, J., Chavarría, D., Ramírez-Cadena, M., \& Molina, A. (2015). Design S3-RF (Sustainable $x$ Smart $x$ Sensing-Reference Framework) for the future manufacturing enterprise. IFAC-PapersOnLine, 48(3), 58-63. http://dx.doi.org/10.1016/j.ifacol.2015.06.058.

Maymand, M. M., Farsijani, H., \& Moosavi, S. S. T. (2012). Investigation of the key success factors in virtual tourism. Indian Journal of Science and Technology, 5(7), 3073-3080.

Mertins, K., \& Jochem, R. (2005). Architectures, methods and tools for enterprise engineering. International Journal of Production Economics, 98(2), 179-188. http://dx.doi.org/10.1016/j.ijpe.2004.05.024

Miranda, J., Pérez-Rodríguez, R., Borja, V., Wright, P. K., \& Molina, A. (2019a). Sensing, smart and sustainable product development $\left(S^{3}\right.$ product) reference framework. International Journal of Production Research, 57(14), 4391-4412.

Miranda, J., Ponce, P., Molina, A., \& Wright, P. (2019b). Sensing, smart and sustainable technologies for Agri-Food 4.0. Computers in Industry, 108, 21-36. http://dx.doi.org/10.1016/j.compind.2019.02.002.

Moisescu, M. A., \& Sacala, I. S. (2016). Towards the development of interoperable sensing systems for the future enterprise. Journal of Intelligent Manufacturing, 27(1), 33-54. http://dx.doi.org/10.1007/s10845-014-0900-0.

Molina, A., Ponce, P., Ramirez, M., \& Sanchez-Ante, G. (2014, october). Designing a S 2enterprise (Smart $x$ Sensing) reference model. In Proceedings of the Working Conference on Virtual Enterprises (pp. 384-395). Berlin, Heidelberg: Springer. http://dx.doi.org/10.1007/978-3-662-44745-1_38.

Musa, A., Gunasekaran, A., Yusuf, Y., \& Abdelazim, A. (2014). Embedded devices for supply chain applications: towards hardware integration of disparate technologies. Expert Systems with Applications, 41(1), 137-155. http://dx.doi.org/10.1016/j.eswa.2013.07.017.

Organização para Cooperação e Desenvolvimento Econômico (2005). Manual de Oslo: proposta de diretrizes para coleta e interpretação de dados sobre inovação tecnológica (3. ed., Trad. Financiadora de Estudos e Projetos-FINEP). Paris: OCDE.

Pádua, S. I. D. (2012). Estudo sobre a aplicação do método de avaliação do Modelo de Processos de Negócio do EKD. Produção, 22(1), 155-172. http://dx.doi.org/10.1590/S0103-65132011005000050. 
Pádua, S. I. D., Cazarini, E. W., \& Inamasu, R. Y. (2004). Modelagem organizacional: captura dos requisitos organizacionais no desenvolvimento de sistemas de informação. Gestão \& Produção, 11(2), 197-209. http://dx.doi.org/10.1590/S0104-530X2004000200006.

Palmer, C., Urwin, E. N., Young, R. I. M., \& Marilungo, E. (2017). A reference ontology approach to support global product-service production. International Journal of Product Lifecycle Management, 10(1), 86-106. http://dx.doi.org/10.1504/IJPLM.2017.083003.

Panetto, H., lung, B., Ivanov, D., Weichhart, G., \& Wang, X. (2019). Challenges for the cyberphysical manufacturing enterprises of the future. Annual Reviews in Control, 47, 200-213. http://dx.doi.org/10.1016/j.arcontrol.2019.02.002.

Peko, G., Dong, C. S., \& Sundaram, D. (2014). Adaptive Sustainable enterprises. Mobile Networks and Applications, 19(5), 608-617. http://dx.doi.org/10.1007/s11036-014-0525-8.

Rajput, S., \& Singh, S. P. (2019). Connecting circular economy and industry 4.0. International Journal of Information Management, 49, 98-113. http://dx.doi.org/10.1016/j.ijinfomgt.2019.03.002.

Ramani, S. V., Thutupalli, A., \& Urias, E. (2017). High-value hi-tech product introduction in emerging countries. Qualitative Market Research, 20(2), 208-225. http://dx.doi.org/10.1108/QMR-01-2017-0034.

Runfola, A., Perna, A., Baraldi, E., \& Gregori, G. L. (2017). The use of qualitative case studies in top business and management journals: A quantitative analysis of recent patterns. European Management Journal, 35(1), 116-127. http://dx.doi.org/10.1016/j.emj.2016.04.001.

Sankuhl, K., Stirna, J., Persson, A., \& Wißotzki, M. (2014). Enterprise modeling: tackling business challenges with the 4EM method. Heidelberg: Springer.

Schumacher, A., Erol, S., \& Sinn, W. (2016). A maturity model for assessing Industry 4.0 readiness and maturity of manufacturing enterprises. Procedia CIRP, 52, 161-166. http://dx.doi.org/10.1016/j.procir.2016.07.040.

Schumpeter, J. A. (2008). Capitalism, socialism, and democracy. New York: Perennial Books.

Seiger, R., Keller, C., Niebling, F., \& Schlegel, T. (2015). Modelling complex and flexible processes for smart cyber-physical environments. Journal of Computational Science, 10, 137-148. http://dx.doi.org/10.1016/j.jocs.2014.07.001.

Shrivastava, P., \& Kennelly, J. J. (2013). Sustainability and place-based enterprise. Organization \& Environment, 26(1), 83-101. http://dx.doi.org/10.1177/1086026612475068.

Stanescu, A. M., Cretan, A., Coutinho, C., \& Jardim-Goncalves, R. (2013). Intelligent negotiation mechanism for supporting the interoperability within the sensing enterprise. IFAC Proceedings Volumes, 46(9), 1328-1333.

Tan, Y., Vuran, M. C., \& Goddard, S. (2009). Spatio-temporal event model for cyber-physical systems. In Proceedings of the 29th IEEE International Conference on Distributed Computing Systems Workshops (pp. 44-50). USA: IEEE. http://dx.doi.org/10.1109/ICDCSW.2009.82.

Tortorella, G. L., Vergara, A. M. C., Garza-Reyes, J. A., \& Sawhney, R. (2019). Organizational learning paths based upon Industry 4.0 adoption: an empirical study with Brazilian manufacturers. International Journal of Production Economics, 219, 284-294. http://dx.doi.org/10.1016/j.ijpe.2019.06.023.

Trentesaux, D., Borangiu, T., \& Thomas, A. (2016). Emerging ICT concepts for smart, safe and sustainable industrial systems. Computers in Industry, 81, 1-10. http://dx.doi.org/10.1016/j.compind.2016.05.001.

Turrioni, J. B., \& Mello, C. H. P. (2012). Metodologia de pesquisa em engenharia de produção: estratégias, métodos e técnicas para condução de pesquisas quantitativas e qualitativas. Itajubá: Universidade Federal de Itajubá. Apostila do curso de Especialização em Qualidade e Produtividade. 
Vargas, A., Cuenca, L., Boza, A., Sacala, I., \& Moisescu, M. (2016). Towards the development of the framework for inter sensing enterprise architecture. Journal of Intelligent Manufacturing, 27(1), 55-72. http://dx.doi.org/10.1007/s10845-014-0901-z.

Veza, I., Mladineo, M., \& Gjeldum, N. (2015). Managing innovative production network of smart factories. IFAC-PapersOnLine, 48(3), 555-560. http://dx.doi.org/10.1016/j.ifacol.2015.06.139.

Voss, C., Tsikriktsis, N., \& Frohlich, M. (2002). Case research in operations management. International Journal of Operations \& Production Management, 22(2), 195-219. http://dx.doi.org/10.1108/01443570210414329.

Weichhart, G., Molina, A., Chen, D., Whitman, L. E., \& Vernadat, F. (2016). Challenges and current developments for sensing, smart and sustainable enterprise systems. Computers in Industry, 79, 34-46. http://dx.doi.org/10.1016/j.compind.2015.07.002.

Wright, P. (2014). Cyber-physical product manufacturing. Manufacturing Letters, 2(2), 49-53. http://dx.doi.org/10.1016/j.mfglet.2013.10.001.

Wu, D., Liu, S., Zhang, L., Terpenny, J., Gao, R. X., Kurfess, T., \& Guzzo, J. A. (2017). A fog computing-based framework for process monitoring and prognosis in cyber-manufacturing. Journal of Manufacturing Systems, 43(part 1), 25-34. http://dx.doi.org/10.1016/j.jmsy.2017.02.011.

Yue, X., Cai, H., Yan, H., Zou, C., \& Zhou, K. (2015). Cloud-assisted industrial cyber-physical systems: an insight. Microprocessors and Microsystems, 39(8), 1262-1270. http://dx.doi.org/10.1016/j.micpro.2015.08.013.

Zdravković, M., Noran, O., \& Trajanovic, M. (2014). Towards sensing information systems. In V. Strahonja, N. Vrček, D. Plantak Vukovac, C. Barry, M. Lang, H. Linger \& C. Schneider (Eds.), Proceedings of the 2014 International Conference on Information Systems Development - Transforming organisations and society through information systems. New York: Springer Verlag.

Zhang, Y., Qian, C., Lv, J., \& Liu, Y. (2017). Agent and cyber-physical system based selforganizing and self-adaptive intelligent shopfloor. IEEE Transactions on Industrial Informatics, 13(2), 737-747. http://dx.doi.org/10.1109/TII.2016.2618892.

Zhong, R. Y., Lan, S., Xu, C., Dai, Q., \& Huang, G. Q. (2016). Visualization of RFID-enabled shopfloor logistics Big Data in Cloud Manufacturing. International Journal of Advanced Manufacturing Technology, 84(1-4), 5-16. http://dx.doi.org/10.1007/s00170-015-7702-1.

Zollo, M., Cennamo, C., \& Neumann, K. (2013). Beyond what and why: understanding organizational evolution towards sustainable enterprise models. Organization \& Environment, 26(3), 241-259. http://dx.doi.org/10.1177/1086026613496433. 